\title{
ANALYSIS OF COUNTY GEOPORTALS IN TERMS OF OPPORTUNITIES TO PURCHASE DATA OF THE REGISTER OF REAL ESTATE PRICES AND VALUES ONLINE
}

\author{
Łukasz Halik, PhD \\ Department of Cartography and Geomatics \\ Adam Mickiewicz University in Poznań \\ e-mail:lukasz.halik@amu.edu.pl
}

\begin{abstract}
We live in an information society for which the Internet, as a global system of connections between computers and, consequently, databases stored in them, plays a highly important part. Hence, more and more real property data are available. This article is devoted to the analysis of the opportunities to purchase the Register of Real Estate Prices and Values (RREPV) online from county geoportals. RREPV is one of the sources of information used in the process of real estate value estimation. Pursuant to $\S 74$ of the Regulation on the Land and Property Register, the register is kept by the head of the county. There are 380 counties in Poland, including 66 city counties. Such a big number of administrative units in Poland, along with a great variety of different information and communication systems used for keeping RREPV, results in the fact that online access to the register data is not possible everywhere. The aim of the paper is to present the spatial layout of counties which: created the opportunity to access the National Geodetic and Cartographic Resource data via county geoportals, launched special modules for handling real estate appraisers and made it possible to purchase RREPV data online.
\end{abstract}

Key words: register of real estates prices and values, RREPV, geoportal, geomatics GIS.

JEL Classification: D80, D89, L85.

Citation: Halik Ł., 2019, Analysis of County Geoportals in Terms of Opportunities to Purchase Data of the Register of Real Estate Prices and Values Online, Real Estate Management and Valuation, vol. 27, no. 1, pp. 69-78.

DOI: 10.2478/remav-2019-0007

\section{Introduction}

Quick access to real estate data is a fundamental element that affects value estimation time. Such access can be guaranteed by the Internet and geographical information system (GIS) technologies that allow one to present and send data concerning real estate. A geoportal, also referred to as a map portal, is the most popular form of spatial data presentation using GIS techniques. As the definition says, a geoportal is a website that provides access to spatial data services (MEDYŃSKA-GULIJ 2017). These allow one to search for, browse through, download, transform and launch other services connected with spatial data.

Analysing existing spatial databases, it needs to be said that the three most important ones used for value estimation are: Land and Property Register, Geodetic Register of Infrastructural Network and Register of Real Estate Prices and Values. The existence of the above databases is regulated by Section 4.1a of the Polish Land Survey and Cartography Act (АCT of 17 May 1989) under which "nationwide databases are established and kept in the information and communication system, including spatial databases of spatial information infrastructure concerning: 2) Land and Property Register (Cadastre), 
3) Geodetic Register of Infrastructural Network, (...) 7) Register of Real Estate Prices and Values." Under Section $7 \mathrm{~d}$, the aforementioned registers are kept by the head of the county at the county level, as specified by the legislator. Hence, it needs to be said that key spatial data necessary for the real estate appraisal procedure are collected at the county level. This is particularly transparent in the Regulation on the Land and Property Register (REGULATION of 29 March 2001), which, in $\S 44$, sets the tasks of the head of the county concerning keeping the register, whereas in $\S 74$, the legislator specifies that "the head of the county is responsible for keeping the register of real estate prices, indicated in notarial deeds, and real property values, determined by real estate appraisers in the real estate appraisal survey" (however, under the latest amendment of the Real Estate Management Act, since September 1 15t 2017, real estate appraisers do not have a duty to transfer records of real estate appraisal surveys to authorities that keep the cadastre, which in practice means that RREPV will not include values of the real estate specified in the carried out real estate appraisal surveys from the abovementioned date). Hence, it seems legitimate to carry out research on the use of county geoportals for presenting and sharing spatial data. The main aim of the article is to demonstrate the spatial layout of counties which: provided the opportunity to access the National Geodetic and Cartographic Resource data via county geoportals, launched special modules for handling real estate appraisers and made it possible to purchase RREPV data online. The second aim is to verify the research hypothesis: in city counties, the percentage of geoportals enabling the purchase of RREPV data online is larger than in land counties.

\section{Literature review}

The review of literature in this paper will refer to: a) geoportals - GIS techniques b) Register of Real Estate Prices and Values. Considering that the value of property is primarily determined by its location (Pagourtzi et al. 2003), people have realized the importance of geographical information system techniques (Rodriguez et al. 1995; Zeng, Zhou 2001; Li et al. 2005). GIS techniques provide not only a geo-database to store relevant data with spatial relationships, but also a visual representation of information. Analyzing Polish scientific literature dedicated to geoportals - GIS techniques and their functioning, one ought to mention the work in which DUKACZEWSKI (2007) demonstrated the development of provincial geoportals in Poland, describing the thematic range of available data, functionality, used methods of cartographic presentation and metadata. The article by DUKACZEWSKI, BIELECKA (2009), which was a comparative analysis of nationwide geoportals from Europe in terms of organizational and technical solutions, thematic range of data and metadata, functionality, access limitations and typology of nationwide geoportals, is also noteworthy. DUKACZEWSKI et al. (2012) carried out a comparative analysis of regional geoportals of selected European countries. IZDEBSKI (2016) worked out a highly useful compendium of knowledge about collecting, storing and sharing spatial data via map portals or, in other words, about basic functions and typical content of a map portal at the county and commune level. IZDEBSKI and MALINOWSKI (2016) published another interesting book devoted to map portals at the commune level, focusing mainly on opportunities to use geoportals for presenting commune registers of spatial data. In literature, one can also find publications about obtaining information about real estate from nationwide geoportals (HALIK 2017).

Land and property transactions play very important roles in governments' revenues and financial institutions' banking policies. Hence, there is great demand for a supply of land price information. Satisfying this demand by means of traditional information presentation, however, is not an easy taskbecause land price is a kind of special geographical information which varies both temporally and spatially (PAZ 2003; CiCHOCIŃSKI, DĄBROWSKI 2013; NANDA, YEH 2014; YANG et al. 2015). In this case, Poland differs from Germany or France, in which cadastral data exchange standards have been introduced for a long time, which unifies the way data is collected in information and communication systems (KARABIN 2002, 2003). This is why it is very important to analyse, in the context of this research, scientific literature concerning the register of real estate prices and values in Poland. It should be mentioned here that the work by KLOCEK, KOWALSKA (2001) was one of the first articles dealing with the topic; it described the experience connected with working out and implementing the technology of keeping RREPV in the head of the county's office in Olsztyn. KURYJ and ŹRÓBEK (2005) analysed RREPV as an integral part of the spatial information system used for monitoring landed estate and the real estate market. BYDŁOSZ and PARZYCH (2007) assessed the opportunities to use RREPV data in the context of real estate appraisal, whereas legal aspects of using RREPV were discussed by SIEWICZ (2012). HOPFER et al. (2012) assessed RREPV with regard to the draft of the 
Regulation on the Integrated Real Estate Information System. One of the first studies of information and communication systems in which RREPV is kept was conducted by BUDZYŃSKI (2012a), who analyszd counties and city counties of Mazovia Province. RREPV as a source of information about real estate was also analyzed in scientific literature in terms of its usefulness for creating cartographic presentations in the form of maps of average transaction prices of lands (BYDŁOSZ et al. 2010; BUDZYŃSKI 2012b). In his research KONOWALCZUK (2014) presents theoretical considerations regarding the needs and criteria of creating ownership divisions of real estate markets for the purpose of public surveys and research using the RREPV from Silesia Province. The problem of the quality of data concerning transaction prices on the real estate market in the aspect of RREPV, along with postulates of suggested legal and organisational changes, was presented by КОКОТ (2015). The information and communication systems and usefulness of RREPV in appraisal by comparative methods, on the basis of Lublin Province registers, was also researched by ZYGA (2016). In the most recent research, ZYGA (2017) presented the usefulness of RREPV data from Lublin Province in real estate appraisal. A work by DAWIDOWICZ and ŹRÓBEK (2017) is one of the latest publications on registering real estate prices and values in the context of the Integrated Real Estate Information System, which is just being implemented in Poland. Scientific publications that touch on a wide range of issues concerning geoportals and RREPV are presented above. It needs to be highlighted that no attempt to analyze county geoportals in terms of the opportunity to purchase RREPV data online has been made so far.

\section{The area of research}

This research constitutes an attempt of a holistic analysis of county geoportals in terms of equipping them with special modules for real estate appraisers and the opportunities to purchase RREPV data online. Hence, 380 counties, including 66 city counties, form the research area (Fig. 1) (ANNOUNCEMENT of 23 August 2017).
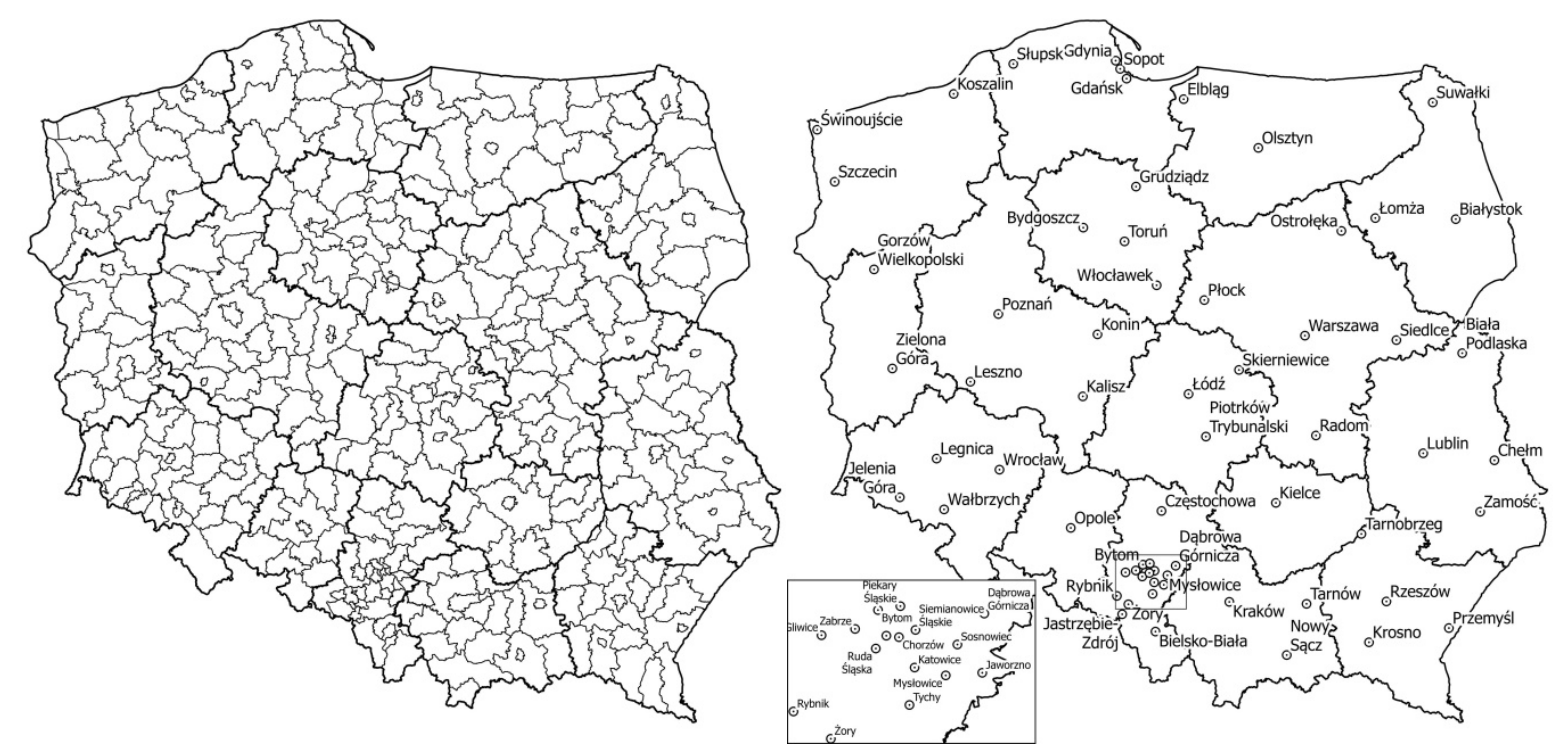

Fig. 1. Maps depicting the 380 counties and localization of 66 city counties. Source: PRG, GUS.

\section{Data and Methods}

The research was conducted at the turn of December 2017 and January 2018. The author worked out a research questionnaire that was sent via the Internet to all counties in Poland. It consisted of 24 questions about the way to keep and present county spatial databases: the Register of Real Estate Prices and Values, the Land and Building Register and the Geodetic Register of Infrastructural Network, all three being a part of the National Geodetic and Cartographic Resource. The main focus was on obtaining information from heads of counties/city mayors on information and communication systems used for the spatial databases mentioned above, the opportunity to buy RREPV data online, additional attributes stored in RREPV besides those described in $\S 74$ of the Regulation on the Land and Property Register (REGULATION of 29 March 2001) and the ways and range of presenting those databases on county geoportals. 
In the questionnaire for heads of counties/city mayors, the following questions, described in this paper, were asked:

- Was the official geoportal (map portal) presenting spatial data implemented and rendered available to citizens in the county/city county that you govern?

- Was a separate module for real estate appraisers worked out as a part of the geoportal (map portal)?

- Is there an opportunity to purchase RREPV data online, using a dedicated module in the geoportal without the necessity of face-to-face contact with the employees of the Centre of Geodetic and Cartographic Documentation?

All 380 counties in Poland answered the questionnaire. This was possible thanks to the provisions of the act on the re-use of public sector information (АСТ of 25 February 2016).

Apart from the data obtained by the author from heads of counties' offices, the spatial database of the National Register of Boundaries stored in the Head Office of Geodesy and Cartography was also used as a cartographic base (GUGiK 2018). Analyses and cartographic visualizations were made in free software QGIS. QGIS is geomatic software used for spatial data management, spatial analyses, creating cartographic 2D and 3D visualizations, and, as it operates the SQL language, it also allows one to query databases very effectively (HALIK 2016).

\section{Empirical results}

Figure 2 depicts the spatial layout of counties whose heads implemented and rendered official county geoportals with the National Geodetic and Cartographic Resource data available to citizens. Comparing this map to Table 1, one can see that 320 out of 380 counties have geoportals, which makes approximately $84.2 \%$. In two provinces, Pomerania Province and Świętokrzyskie Province, all counties have geoportals. The smallest number of geoportals was established and rendered available in counties of Warmia-Masuria Province. In the analysis of city counties (Table 2), it has to be highlighted that as many as 64 out of 66 city counties have official geoportals $(97 \%)$.

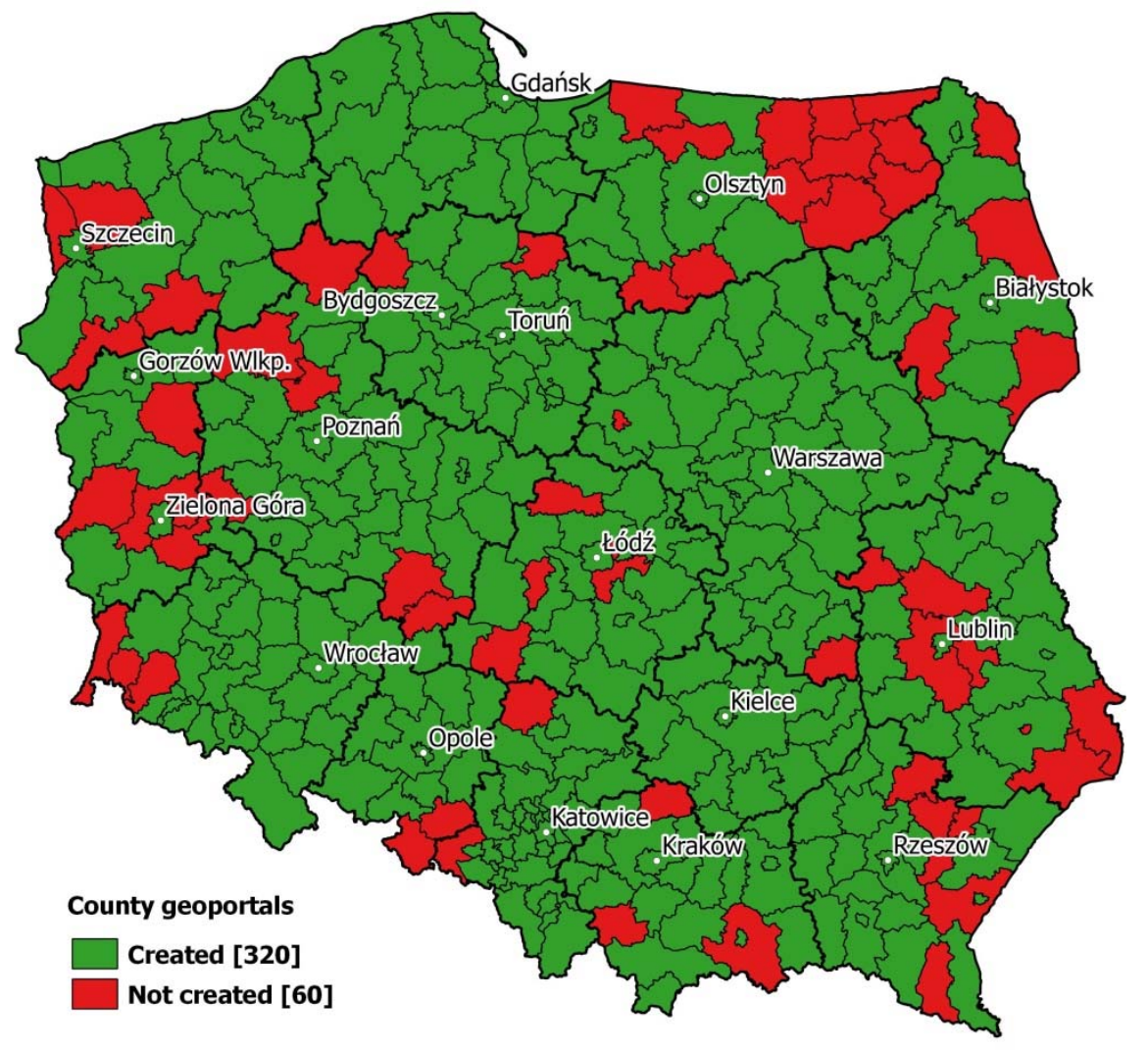

Fig. 2. Map depicting the creation of county geoportals (January 2018). Source: own study.

Geoportals can be equipped with special modules for specific target groups of highly specialized needs: real estate appraisers, land surveyors, court debt collectors. A module in this article needs to be understood as a specially prepared version of a geoportal, usually protected with a password, which 
offers access to more data than in the regular version. Those are usually sensitive data, such as personal data that are protected under the Personal Data Protection Act (ANNOUNCEMENT of 3 June 2016). From the perspective of a real estate appraiser, the existence of such a module may facilitate direct access to RREPV data, including the location of transactions on the map base and advanced mechanisms of data filtering. Access to scans of notarial deeds as main source documents that constitute the basis of RREPV records is another important functional feature. Figure 3 depicts the spatial layout of 91 counties, which makes $24 \%$ of all counties that created special modules for real estate appraisers. Comparing the map below to Table 1, one can see that the most modules were implemented in Lower Silesia (14) and Greater Poland Province (11), and the least in Świętokrzyskie (2) and Warmia-Masuria Province (2). As far as city counties (Table 2) are concerned, the most modules were implemented in Lubuskie (2) and Łódź (2) Province, whereas no modules whatsoever were implemented in city counties from Kujawy-Pomerania, Opole and Świętokrzyskie Province.

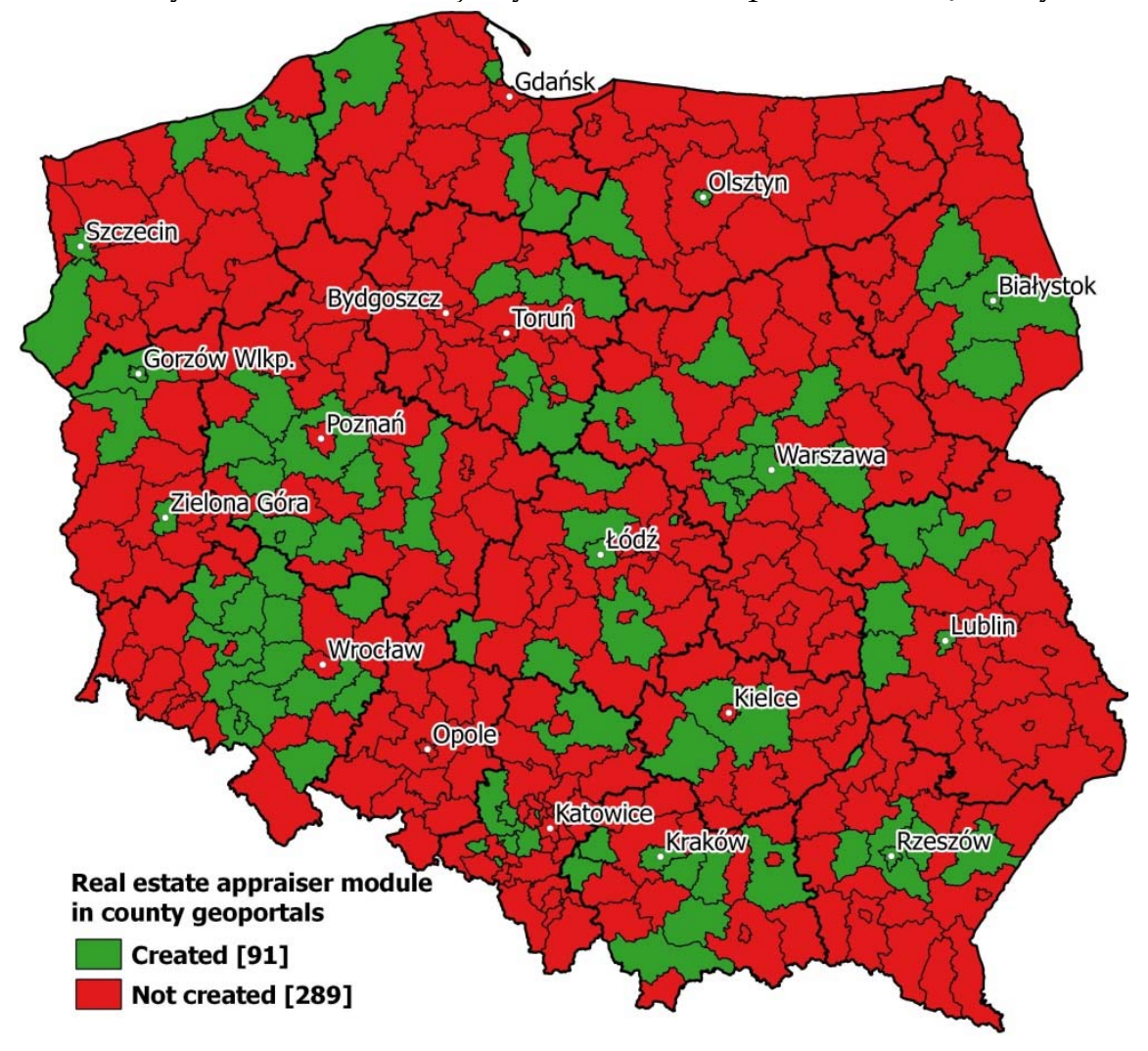

Fig. 3. Map depicting the creation of real estate appraiser module in county geoportals (January 2018). Source: own study.

The opportunity to purchase RREPV data collected by the head of the county's office online is the last issue analyzed in the article. This is the highest level of use of Internet technologies combined with online payments that can serve citizens. Rendering such a service available by heads of counties deserves credit as it significantly shortens the time necessary for purchasing data, lowers costs and eliminates the time connected with commuting to the office, at the same time forcing the pace of the appraisal process. Real estate appraisers can order necessary data at any time without leaving their house and receive them immediately after making a payment. Figure 4 depicts the spatial layout of counties that have launched the service of online RREPV data purchase. Currently (January 2018) there are 76 of them (20\% of all counties). Analyzing the spatial layout in provinces, it needs to be observed that the most of such services were launched in Lower Silesia (13) Province, whereas in Opole Province, no such services were launched whatsoever. On the basis of Table 2 concerning city counties, one can conclude that such opportunity was created in 16 out of 66 cities (24\% of all city counties). The most services were launched in: Lubuskie (2) and West Pomerania (2) Province, whereas in Opole and Świętokrzyskie Province, no city county launched such a service. 


\section{sciendo}

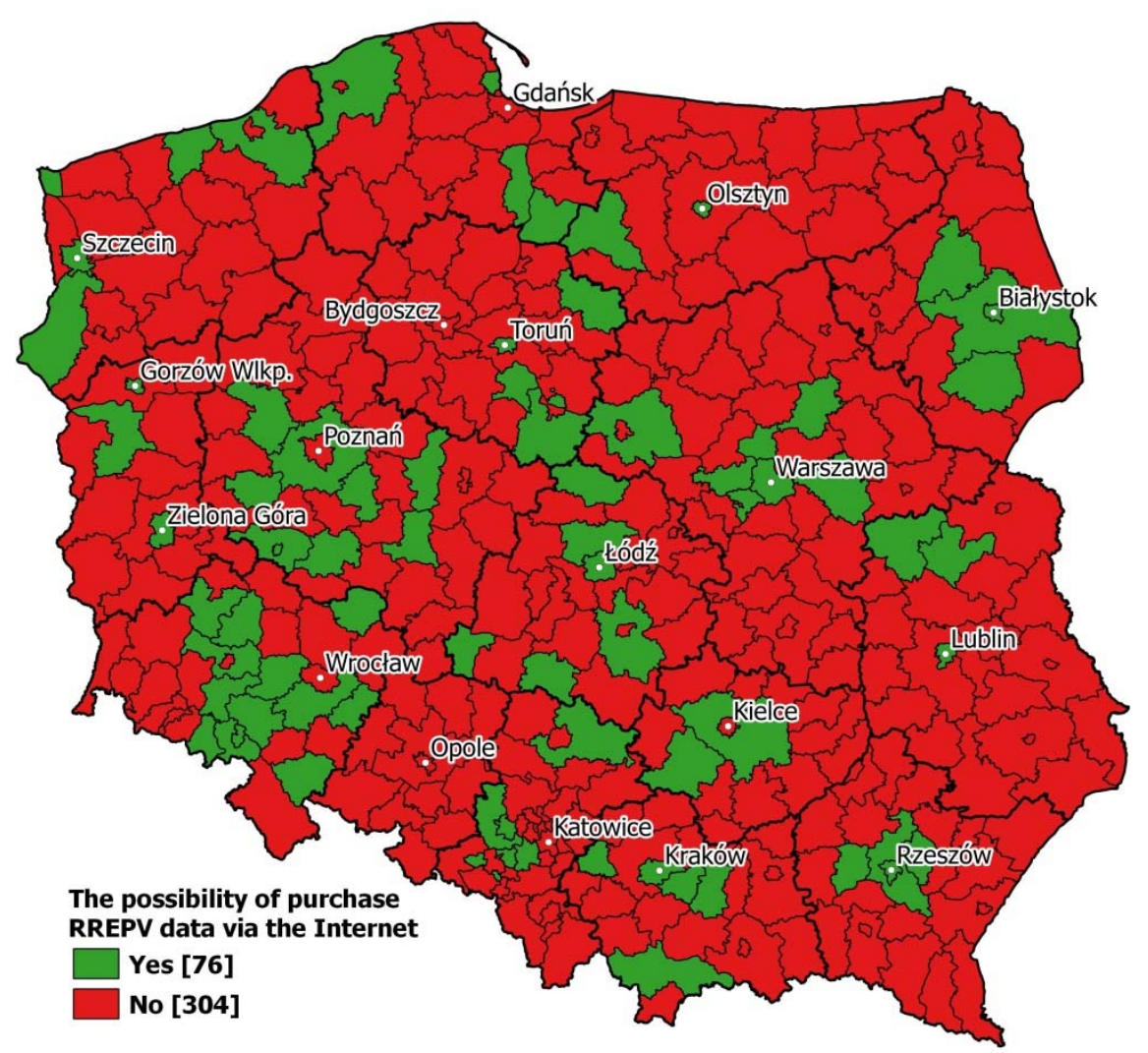

Fig. 4. Map depicting the possibility of purchase RREPV data online from county geoportals (January 2018). Source: own study.

Table 1

Geoportals, real appraiser's modules and purchase of RREPV data online in Poland

\begin{tabular}{|c|c|c|c|c|}
\hline Provinces & $\begin{array}{l}\text { Number of } \\
\text { counties }\end{array}$ & $\begin{array}{c}\text { Number of } \\
\text { county } \\
\text { geoportals }\end{array}$ & $\begin{array}{c}\text { Number of real } \\
\text { estate } \\
\text { appraiser's } \\
\text { modules in } \\
\text { county } \\
\text { geoportals }\end{array}$ & $\begin{array}{l}\text { Number of } \\
\text { counties where } \\
\text { one can buy } \\
\text { RREPV data } \\
\text { online }\end{array}$ \\
\hline DOLNOŚLĄSKIE & 30 & 27 & 14 & 13 \\
\hline KUJAWSKO-POMORSKIE & 23 & 21 & 5 & 4 \\
\hline LUBELSKIE & 24 & 17 & 5 & 3 \\
\hline LUBUSKIE & 14 & 10 & 4 & 3 \\
\hline ŁÓDZKIE & 24 & 20 & 7 & 6 \\
\hline MAZOWIECKIE & 42 & 40 & 9 & 7 \\
\hline MAŁOPOLSKIE & 22 & 19 & 8 & 5 \\
\hline OPOLSKIE & 12 & 10 & 0 & 0 \\
\hline PODKARPACKIE & 25 & 20 & 6 & 4 \\
\hline PODLASKIE & 17 & 13 & 4 & 4 \\
\hline POMORSKIE & 20 & 20 & 4 & 4 \\
\hline ŚLĄSKIE & 36 & 34 & 6 & 5 \\
\hline ŚWIĘTOKRZYSKIE & 14 & 14 & 2 & 2 \\
\hline WARMIŃSKO-MAZURSKIE & 21 & 9 & 2 & 2 \\
\hline WIELKOPOLSKIE & 35 & 29 & 11 & 9 \\
\hline
\end{tabular}




\section{S sciendo}

\begin{tabular}{lccccc}
\hline ZACHODNIOPOMORSKIE & 21 & 17 & 4 & 5 \\
\hline & $\sum$ & $\mathbf{3 8 0}$ & $\mathbf{3 2 0}$ & $\mathbf{9 1}$ & $\mathbf{7 6}$ \\
\hline
\end{tabular}

Source: own study.

Table 2

Geoportals, real appraiser's modules and purchase of RREPV data online in county cities

\begin{tabular}{|c|c|c|c|c|}
\hline Provinces & $\begin{array}{c}\text { Number of } \\
\text { city } \\
\text { counties }\end{array}$ & $\begin{array}{l}\text { Number of } \\
\text { city county } \\
\text { geoportals }\end{array}$ & $\begin{array}{l}\text { Number of } \\
\text { real estate } \\
\text { appraiser's } \\
\text { modules in } \\
\text { city county } \\
\text { geoportals }\end{array}$ & $\begin{array}{l}\text { Number of city } \\
\text { county where one } \\
\text { can buy RREPV } \\
\text { data online }\end{array}$ \\
\hline DOLNOŚLĄSKIE & 4 & 4 & 1 & 1 \\
\hline KUJAWSKO-POMORSKIE & 4 & 4 & 0 & 1 \\
\hline LUBELSKIE & 4 & 3 & 1 & 1 \\
\hline LUBUSKIE & 2 & 2 & 2 & 2 \\
\hline ŁÓDZKIE & 3 & 3 & 2 & 1 \\
\hline MAZOWIECKIE & 5 & 4 & 1 & 1 \\
\hline MAŁOPOLSKIE & 3 & 3 & 1 & 1 \\
\hline OPOLSKIE & 1 & 1 & 0 & 0 \\
\hline PODKARPACKIE & 4 & 4 & 2 & 1 \\
\hline PODLASKIE & 3 & 3 & 1 & 1 \\
\hline POMORSKIE & 4 & 4 & 1 & 1 \\
\hline ŚLĄSKIE & 19 & 19 & 2 & 1 \\
\hline ŚWIĘTOKRZYSKIE & 1 & 1 & 0 & 0 \\
\hline WARMIŃSKO-MAZURSKIE & 2 & 2 & 1 & 1 \\
\hline WIELKOPOLSKIE & 4 & 4 & 2 & 1 \\
\hline ZACHODNIOPOMORSKIE & 3 & 3 & 1 & 2 \\
\hline 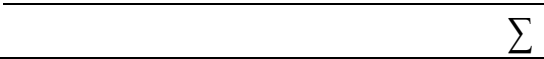 & 66 & 64 & 18 & 16 \\
\hline
\end{tabular}

Source: own study.

\section{Discussion and conclusions}

According to the established scientific hypothesis, it was verified that, in Poland, in city counties (24.2\%) more geoportals were launched where you can buy RREPV data online than in land counties $(19.1 \%)$. From the conducted research, it transpires that $84.2 \%$ of all counties offered the opportunity to access the National Geodetic and Cartographic Resource via county geoportals, $24 \%$ of all counties launched special modules to be used by real estate appraisers and $20 \%$ of all counties made it possible to purchase RREPV data online. The demonstrated results prove that the majority of counties are aware of benefits from presenting spatial data on the Internet.

Unfortunately, there is still room for improvement when it comes to issues connected with the facilitation of the process of serving real estate appraisers in the form of dedicated modules and opportunities to purchase data online. Additional costs that need to be incurred in the process of geoportal creation may be one of possible reasons for this. However, it needs to be emphasised that costs of providing for real estate appraisers online, incurred at the beginning, will pay off with interest as they will allow employees of Centres of Geodetic and Cartographic Documentation to be directed to other activities connected with handling and digitalizing the National Geodetic and Cartographic Resource.

The results of the research can be seen in the online map application created by the author of this article, which can be accessed at: https://maparciwn.pl (Fig. 5). The application works both on desktop computers and smartphones in the field (Chrome Mobile is the recommended search engine). 
The author intended the website to be a support tool for people dealing with the real estate market. The website may provide information about: the type of the information and communication system used in a specific county, formats of the data which makes it possible to export them from RREP and additional attributes included in RREPV but not mentioned in $§ 74$ of the Regulation on the Land and Property Register.

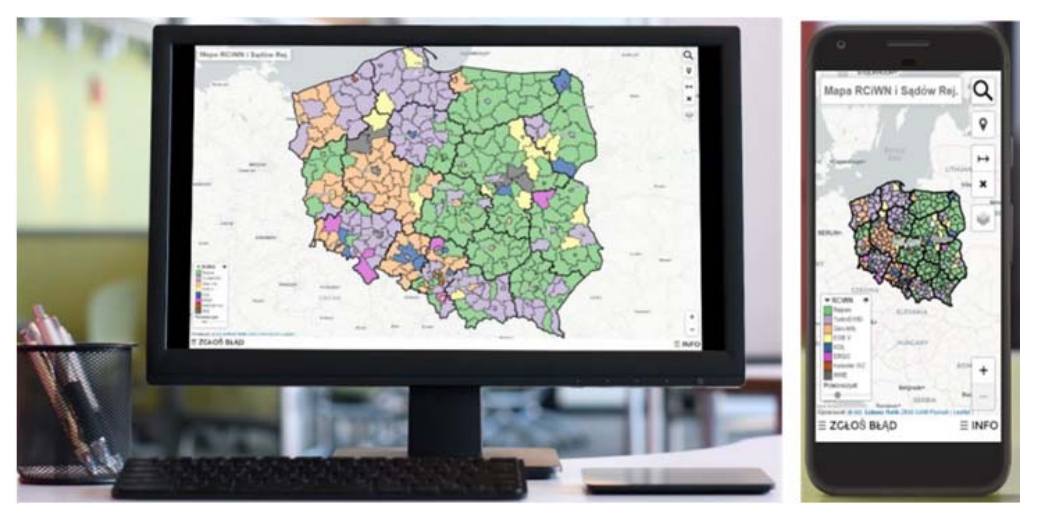

Fig. 5. View of the https:/ / maparciwn.pl on a desktop and smartphone device. Source: own study.

The author realizes that this article does not exhaust the topic but hopes that it will initiate further debate about how to facilitate the process of obtaining data for appraisal in terms of information and communication tools applied in public administration.

\section{References}

BUDZYŃSKI T., 2012a, Rejestr cen i wartości nieruchomości jako źródło danych dla potrzeb analizy rynku nieruchomości (Register of Real Estate Price and Value as a Source of Data for the Purposes of Real Estate Market Analysis), Rzeczoznawca Majątkowy, Vol. 74, No. 2, pp. 25-29.

BUDZYŃSKI T., 2012b, Propozycje zastosowań mapy średnich cen transakcyjnych gruntów w gospodarce nieruchomościami (Proposals for the Use of Maps of Average Transaction Prices of Land in Real Estate Management), Studia i Materiały Towarzystwa Naukowego Nieruchomości, Vol. 20, No. 1, pp. 135144.

BYDŁOSZ J., PARZYCH P., 2007, Ocena możliwości wykorzystania danych rejestru cen i wartości nieruchomości na potrzeby wyceny nieruchomości (Assessment of the Possibility to Use the Register of Real Estate Price and Value Data for Property Valuation Purposes), Geomatics and Environmental Engineering, Vol. 1, No. 4, pp. 31-40.

BYDŁOsZ J., CichOCIŃSKI P., PARZYCH P., 2010, Możliwości wykorzystania danych rejestru cen i wartości nieruchomości na potrzeby gospodarki przestrzennej (Possibilities of Using Data from the Register of Real Estate Price and Value for the Needs of Spatial Management), Acta Scientiarum Polonorum Administratio Locorum, Vol. 9, No. 1, pp. 5-16.

CiCHOCIŃSKI P., DĄBROWSKI J., 2013, Spatio-temporal Analysis of the Real Estate Market Using Geographic Information Systems. Real Estate Management and Valuation, Vol. 21, No. 2, pp. 72-82.

DAWIDOWICZ A., ŹRÓBEK R., 2017, Land Administration System for Sustainable Development - Case Study of Poland, Real Estate Management and Valuation, Vol. 25, No. 1, pp. 112-122.

DUKACZEWSKI D., 2007, Wojewódzkie portale informacji przestrzennej (Voivodship Spatial Information Portals), Roczniki Geomatyki, Vol. 5, No. 3, pp. 37-56.

DUKACZEWSKI D., BIELECKA E., 2009, Analiza porównawcza krajowych geoportali w Europie (Comparative Analysis of National Geoportals in Europe), Roczniki Geomatyki, Vol. 7, No. 6, pp. 35-60.

DUKACZEWSKI D., CIOŁKOSZ-STYK A., SOCHACKI M., 2012, Geoportale regionalne wybranych krajów Europy - studium porównawcze (Regional Geoportals of Selected European Countries - a Comparative Study), Roczniki geomatyki, Vol. 10, No. 4, pp. 77-93.

GUGiK, (2018, March 18). Państwowy Rejestr Granic (State Register of Borders.). Retrieved from http:// www.gugik.gov.pl/geodezja-i-kartografia/pzgik/dane-bez-oplat/dane-z-panstwowegorejestru-granic-i-powierzchni-jednostek-podzialow-terytorialnych-kraju-prg.

HALIK Ł., 2016, Zastosowanie geomatyki w gospodarce nieruchomościami - pozyskiwanie danych przestrzennych (Appliance of Geomatics in Real Estate Management - Obtaining Spatial Data), Problemy rynku nieruchomości, Vol. 46, pp. 76-87. 
HALIK Ł., 2017, Pozyskiwanie informacji o nieruchmościach z geoportali szczebla krajowego (Acquiring Information about Real Estate from National Geoportals), Rzeczoznawca Majątkowy, Vol. 93, No. 1, pp. 3-7.

Hopfer A., CEgIElSKi S., PIETRZAK L., 2012, Rejestr cen i wartości nieruchomości w świetle projektu rozporządzenia rady ministrów w sprawie zintegrowanego systemu informacji o nieruchomościach - wpływ rozporzadzenia na jakość i wiarygodność RCiWN (The Register of Real Estate Prices and Values in the Light of the Draft Regulation of the Council of Ministers Regarding the Integrated Real Estate Information System - the Impact of the Regulation on the Quality and Credibility of the RREPV), Rzeczoznawca Majactkowy, Vol. 74, pp. 4-11.

IZDEBSKI W., 2016, Dobre praktyki udziatu gmin $i$ powiatów w tworzeniu infrastruktury danych przestrzennych w Polsce (Good Practices of the Participation of Communes and Poviats in the Creation of Spatial Data Infrastructure in Poland), Geo-System Sp. z o.o., Warszawa.

IZDEBSKI W., MALINOWSKI Z., 2016, Dobre praktyki wykorzystania danych przestrzennych w zarzadzaniu gmina (Good Practices in the Use of Spatial Data in Municipal Management), Geo-System Sp. z o.o., Warszawa.

KLOCEK M., KOWALSKA M., 2001, Doświadczenia zwiąane z opracowaniem $i$ wdrożeniem technologii prowadzenia Rejestru Cen i Wartości Nieruchomości (Experience Related to the Development and Implementation of Technology for Maintaining the Register of Real Estate Price and Value), Przegląd Geodezyjny, Vol. 73, No. 7, pp. 10-12.

KARABIN M., 2002, Charakterystyka systemu katastralnego w Niemczech (Characteristics of the Cadastral System in Germany). Przegląd Geodezyjny, Vol. 74, No. 12, pp. 18-22.

KARABIN M., 2003, System katastralny we Francji (Cadastral System in France). Przegląd Geodezyjny, Vol. 75, No. 4, pp. 17-23.

КОКОт S., 2015, Jakość danych o cenach transakcyjnych na rynku nieruchomości (The Quality of Data on Transaction Prices on the Real Estate Market), Acta Scientiarum Polonorum - Administratio Locorum, Vol. 14, No. 1, pp. 43-49.

KONOWALCZUK J., 2014, The corporate real estate market in public statistics in Poland, Real Estate Management and Valuation, Vol. 22, No. 2, pp. 41-51.

KURYJ J., ŹRÓBEK S., 2005, Koncepcja rejestru cen i wartości nieruchomości jako integralnej części systemu informacji o nieruchomościach (The Concept of Register of Real Estate Price and Value as an Integral Part of the Real Estate Information System), Przegląd Geodezyjny, Vol. 77, No. 10, pp. 3-8.

Li H., YU L., CHENG E. W., 2005, A GIS-based Site Selection System for Real Estate Projects. Construction Innovation, Vol. 5, No. 4, pp. 231-241.

MEDYŃSKA-Gulij B., 2017, Kartografia. Zasady i zastosowania geowizualizacji (Cartography. Principles and Applications of Geovisualization). Państwowe Wydawnictwo Naukowe, Warszawa.

NANDA A., YEH J., 2014, Spatio-temporal Diffusion of Residential Land Prices across Taipei Regions. SpringerPlus, vol. 3, pp. 505-520.

Obwieszczenie Marszałka Sejmu Rzeczypospolitej Polskiej z dnia 13 czerwca 2016 r. w sprawie ogłoszenia jednolitego tekstu ustawy o ochronie danych osobowych, Dz.U. 2016 poz. 922 (Announcement of the Speaker of the Sejm of the Republic of Poland of June 13, 2016 regarding the publication of a uniform text of the Act on the Protection of Personal Data, Journal of Laws, 2016 item 922).

Obwieszczenie Prezesa Rady Ministrów z dnia 23 sierpnia 2017 r. w sprawie wykazu gmin i powiatów wchodzacych w skład województw, M.P. 2017 poz. 853 (Announcement of the Prime Minister of the Council of Ministers of 23 August 2017 on the list of communes and poviats included in voivodships, M.P. 2017 item 853).

Pagourtzi E., Assimakopoulos V., Hatzichristos T., French N., 2003, Real Estate Appraisal: A Review of Valuation Methods. Journal of Property Investment \& Finance, Vol. 21, No. 4, pp. 383-401.

PAZ P., 2003, Determinants of Housing Prices in Spanish Cities. Journal of Property Investment and Finance, Vol. 21, No. 2, pp. 109-135.

RODRIGUEZ M., SIRMANS C. F., MARKS A. P., 1995, Using Geographic Information Systems to Improve Real Estate Analysis. Journal of Real Estate Research, Vol. 10, No. 2, pp. 163-174.

Rozporządzenie Ministra Rozwoju Regionalnego i Budownictwa z dnia 29 marca 2001 w sprawie ewidencji gruntów i budynków, Dz. U. z 2001 r. nr 38, poz. 454, z późn. zm. (Regulation of the Minister of Regional Development and Construction of 29 March 2001 on the land and building register, Journal of Laws, 2001, No. 38, Item 454, as ammended). 
SIEWICZ K., 2012, Prawne aspekty korzystania z rejestru cen i wartości nieruchomości (Legal Issues of Using Real Estate Price and Value Registry), Roczniki Geomatyki, No. 10 (3), pp. 126-135.

Ustawa z dnia 17 maja 1989 r. prawo geodezyjne i kartograficzne, Dz. U. 1989 nr 30 poz. 163, z późn. zm. (Act of 17 May 1989 cartographic and geodetic law, Journal of Laws, 1989, No. 30, item 163, as amended).

Ustawa z dnia 25 lutego 2016 r. o ponownym wykorzystywaniu informacji sektora publicznego, Dz.U. 2016 poz. 352 (Act of 25 February 2016 on the re-use of public sector information, Journal of Laws, 2016, item 352)

YANG Y., Sun Y., Li S., ZhANG S., WANG K., Hou H., Xu S., 2015, A GIS-Based Approach for Serving Land Price Information. ISPRS International Journal of Geo-Information, Vol. 4, pp. 2078-2093.

ZENG T. Q., ZHOU Q. M., 2001, Optimal Spatial Decision Making Using GIS: A Prototype of a Real Estate Geographical Information System (REGIS). International Journal of Geographical Information Science, vol. 15, no. 4, pp. 307-321.

ZyGA J., 2016, The Usefulness of Real Estate Prices and Values Register in Appraisal by Comparative Methods, on the Basis of Lublin Voivodeship Registers, Infrastructure and Ecology of Rural Areas, Vol. 4, No. 3, pp. 1673-1688.

ZYGA J., 2017, Przydatność danych zawartych $w$ rejestrze cen $i$ wartości nieruchomości $w$ wycenie nieruchomości (The Usefulness of Data Available in the Real Property Prices and Values Register for the Valuation of Property), Rzeczoznawca Majątkowy, No. 3, pp. 22-25. 